\title{
Maslinic acid inhibits the metastatic capacity of DU145 human prostate cancer cells: possible mediation via hypoxia-inducible factor-1 $\alpha$ signalling
}

\author{
So Young Park ${ }^{1,2}$, Chu Won Nho ${ }^{3}$, Dae Young Kwon ${ }^{4}$, Young-Hee Kang ${ }^{1}$, Ki Won Lee ${ }^{2}$ and \\ Jung Han Yoon Park ${ }^{1 *}$ \\ ${ }^{1}$ Department of Food Science and Nutrition, Research Institute for Bioscience and Biotechnology, Hallym University, 39 \\ Hallymdaehak-gil, Chuncheon 200-702, Republic of Korea \\ ${ }^{2}$ Department of Agricultural Biotechnology, Center for Agricultural Biomaterials, Seoul National University, Seoul 151-921, \\ Republic of Korea \\ ${ }^{3}$ Functional Food Center, Korea Institute of Science and Technology, Gangneung Institute, Gangneung 210-340, Republic of \\ Korea \\ ${ }^{4}$ Korea Food Research Institute, Seongnam 463-746, Republic of Korea
}

(Submitted 13 October 2011 - Final revision received 14 February 2012 - Accepted 14 February 2012 - First published online 13 April 2012)

\begin{abstract}
Maslinic acid is found in various natural sources, most notably in pomace olive oil, and exerts pro-apoptotic activities in various cancer cells in vitro. In the present study, DU145 human prostate cancer cells were cultured with $0-25 \mu \mathrm{m}$-maslinic acid to examine the effects of maslinic acid on the metastatic capacity of prostate cancer cells. Maslinic acid significantly $(P<0.05)$ inhibited the basal and epidermal growth factor (EGF)-induced migration (27-64\%), invasion (23-60\%) and adhesion (8-40\%) of DU145 cells. Maslinic acid significantly $(P<0.05)$ down-regulated both basal and EGF-stimulated secretion of matrix metalloproteinase (MMP)-9 (25-67\%), MMP-2 (50-86\%), urokinase-type plasminogen activator (uPA, about 100\%), vascular endothelial growth factor (VEGF, 98-100\%) and tissue inhibitors of metalloproteinases (TIMP)-1, as well as expression of UPA receptor (uPAR), intercellular adhesion molecules (22-33\%), vascular cell adhesion molecules (23-46\%) and E-cadherin, whereas it increased TIMP-2 secretion. Maslinic acid dramatically reduced the levels of hypoxia-inducible factor- $1 \alpha$ (HIF- $1 \alpha$ ) protein and mRNA; the reduction was accompanied by reduced stability, nuclear levels and transcriptional activity of HIF-1 $\alpha$. The levels of phospho-Akt and phospho-extracellular signal-related kinase (ERK) were reduced in cells treated with maslinic acid, and the phosphoinositide 3-kinase inhibitor LY294002 and the mitogen-activated protein kinase kinase inhibitor PD98059 reduced HIF-1 $\alpha$ levels and VEGF secretion. The results show that maslinic acid markedly inhibited the migration, invasion and adhesion of DU145 prostate cancer cells. Suppressing HIF-1 $\alpha$ activation by inhibiting Akt and ERK activation may be part of the mechanism by which maslinic acid inhibited UPAR, E-cadherin, VEGF and MMP expression in DU145 cells.
\end{abstract}

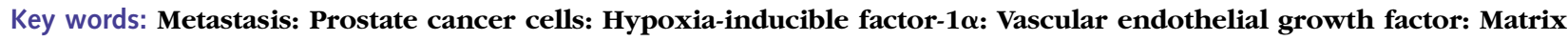
metalloproteinase

Prostate cancer is the second leading cause of cancer-related death in men in Western countries ${ }^{(1)}$. Despite tremendous improvements in cancer treatment methods over the past few decades, $20-30 \%$ of patients will relapse ${ }^{(2)}$. Androgen ablation is a routine form of prostate cancer therapy. However, after an initial response, androgen-insensitive clones can appear, which results in cancer progression and metastasis with high mortality ${ }^{(3)}$. Few successful curative therapies currently exist for metastatic prostate cancer. As prostate cancer is usually diagnosed in older-aged men and progresses slowly to detectable malignancy, considerable efforts have been made to identify bioactive food components to prevent and/or intervene in prostate cancer ${ }^{(4,5)}$.

Bioactive food components are an excellent source of antitumoral agents, because they have low toxicity and multiple molecular targets. Maslinic acid, a natural pentacyclic triterpene acid, is widely present in edible plants, particularly in olive fruits, and exhibits potential anti-tumour activities such

Abbreviations: DMEM, Dulbecco's modified Eagle's medium; EGF, epidermal growth factor; F12, nutrient mixture Ham's F12; HIF, hypoxia-inducible factor; HRE, hypoxia-responsive element; ICAM, intercellular adhesion molecule; MMP, matrix metalloproteinases; TIMP, tissue inhibitors of metalloproteinases; uPA, urokinase-type plasminogen activator; uPAR, urokinase-type plasminogen activator receptor; VCAM, vascular cell adhesion molecule; VEGF, vascular endothelial growth factor.

*Corresponding author: J. H. Y. Park, fax +82 33256 0199, email jyoon@hallym.ac.kr 
as induction of apoptosis in $\mathrm{CacO} 2$ and HT29 colon cancer cells $^{(6,7)}$ and $1321 \mathrm{~N} 1$ astrocytoma cells in vitro ${ }^{(8)}$.

A variety of proteins, such as matrix-degrading proteases, adhesion molecules and motility factors, play crucial roles in tumour invasion and metastasis ${ }^{(9)}$. Tumour metastasis is supported by the increased proteolytic activity of active matrix metalloproteinases (MMP) and urokinase-type plasminogen activator (UPA) secreted by tumour cells or stromal cells ${ }^{(10,11)}$. MMP, particularly MMP-9 and MMP-2, are involved in the degradation of the extracellular matrix and the basement membrane ${ }^{(12)}$. Tissue inhibitors of metalloproteinases (TIMP) are endogenous MMP inhibitors, which are also commonly expressed at tumour sites ${ }^{(13)}$. Both TIMP-1 and TIMP-2 inhibit MMP activity, but TIMP-1 appears to promote cancer metastasis rather than inhibit the process. Elevated TIMP-1 levels are associated with a poor prognosis in a wide variety of cancers (reviewed in Duffy et al. ${ }^{(14)}$ ). The uPA system is one of the serine proteinase systems involved in extracellular matrix degradation and plays a major role in the migration, invasion, adhesion and metastasis of cancer cells, thus making it an important target for anticancer drug therapy ${ }^{(11)}$. Cellular adhesion molecules are glycoproteins expressed on the cell membrane surface. Cellular adhesion molecules are involved in cell signalling, migration, proliferation and differentiation, and function as regulators of tumour progression and metastasis (reviewed in Patriarca et al. ${ }^{(15)}$ and van der Gun et al. $\left.{ }^{(16)}\right)$.

Hypoxia is a key trait of tumours, and virtually all solid tumours contain hypoxic regions in which oxygen concentrations are markedly reduced compared with adjacent normal tissues. Angiogenesis is the formation of new blood vessels from pre-existing vessels and is required for tumour growth and metastasis ${ }^{(17)}$. The family of hypoxia-inducible factors (HIF) is a key regulator of angiogenesis in mammalian tissues in response to oxygen deficiency. HIF-1 is a heterodimeric transcriptional factor composed of $\alpha$ - and $\beta$-subunits. Under normoxic conditions, HIF- $1 \alpha$ is constitutively expressed but rapidly degraded by the ubiquitin-proteasome pathway $^{(18)}$. However, under hypoxic conditions, the blockade of prolyl hydroxylation, ubiquitination and degradation results in the extraordinary accumulation of HIF- $1 \alpha$ and the subsequent translocation of the protein to the nucleus ${ }^{(19)}$. HIF$1 \alpha$ is overexpressed in many human cancers, and its activity is associated with tumour growth, metastasis and angiogenesis $^{(20-22)}$. In the majority of experimental systems, HIF- $1 \alpha$ induced the transcription of vascular endothelial growth factor (VEGF), which is one of the most ubiquitous and potent angiogenic factors and plays a critical role in tumour angiogenesis (reviewed in Rankin \& Giaccia ${ }^{(23)}$ and Hicklin \& Ellis ${ }^{(24)}$ ). As neovascularisation is critical for tumour growth and metastasis, targeting the HIF-1 $\alpha$ /VEGF system is a promising strategy for preventing and treating cancers. In addition to VEGF, HIF- $1 \alpha$ can directly alter the expression of a number of pro-tumorigenic factors, including VEGF receptors, plasminogen activator inhibitor-1, uPA receptor (UPAR), E-cadherin, MMP-2 and MMP-9 ${ }^{(23,25)}$.

The principal objective of the present study was to examine the effects of maslinic acid on the metastatic capacity of androgen-insensitive DU145 prostate cancer cells. The present findings demonstrated that maslinic acid inhibits the migration, invasion and adhesion of DU145 cells. We also demonstrated that maslinic acid inhibits the secretion of VEGF, MMP and UPA, and the expression of uPAR and adhesion molecules. The present results suggest that maslinic acid reduced HIF- $1 \alpha$ activity, which contributed to decreased levels of MMP, VEGF, uPAR and E-cadherin in DU145 cells.

\section{Materials and methods}

\section{Materials}

The reagents used were as follows: maslinic acid (Cayman Chemical); antibodies against UPAR, TIMP-1, TIMP-2, intercellular adhesion molecule (ICAM), vascular cell adhesion molecule (VCAM) and VEGF (Santa Cruz Biotechnology); antibodies against Akt, phospho-Akt, ERK1/2 and phosphoERK1/2 (Cell Signaling Technology); anti-uPA antibody (Calbiochem); anti-HIF- $1 \alpha$, anti-E-cadherin and Matrigel ${ }^{\mathrm{TM}}$ Matrix (BD Biosciences); epidermal growth factor (EGF; R\&D Systems); an adhesion assay kit (Chemicon International); transwell filters (Costar). All other materials were obtained from Sigma.

\section{Cell culture}

DU145 and TRAMP-C2 mouse prostate cancer cells were obtained from the American Type Culture Collection. Cells were maintained in Dulbecco's modified Eagle's medium (DMEM)/nutrient mixture Ham's F12 (F12) with 10\% fetal bovine serum, $62.5 \mathrm{mg} / \mathrm{l}(100000 \mathrm{U} / \mathrm{l})$ of penicillin and $100 \mathrm{mg} / \mathrm{l}$ of streptomycin (Gibco BRL) at $5 \% \mathrm{CO}_{2}$ and $37^{\circ} \mathrm{C}$. To induce hypoxia, cells were placed in an automatic airjacketed multi-gas incubator (MCO-18M; Sanyo) and flushed with a mixture of $1 \% \mathrm{O}_{2}, 5 \% \mathrm{CO}_{2}$ and $94 \% \mathrm{~N}_{2}$.

\section{Migration, invasion and adhesion assays}

Transwell migration assays were conducted, as described previously, to examine whether maslinic acid inhibits the migration of DU145 and TRAMP-C2 cells ${ }^{(26)}$. Briefly, cells were serumdeprived in DMEM/F12 medium supplemented with $1 \%$ charcoal-stripped fetal bovine serum for $24 \mathrm{~h}$. Cells $\left(2.5 \times 10^{4}\right.$ cells/ filter) were then plated onto transwell filters in a twenty-fourwell plate. The transwell filter was precoated with $10 \mu \mathrm{g}$ type IV collagen. The lower chambers of the wells were filled with DMEM/F12 medium containing 1\% charcoal-stripped fetal bovine serum. Bovine serum albumin $(0.1 \%)$ in the absence or presence of $10 \mathrm{ng} / \mathrm{ml}$ EGF was added as a chemoattractant. Cells were incubated with $0-25 \mu \mathrm{m}$-maslinic acid, and the migrated cells were stained with haematoxylin and eosin. The same procedures were conducted for the invasion assay, except that a Matrigel-coated transwell filter (BD Biosciences) was used instead of the collagen-coated filter. For the adhesion assay, cells were plated in human collagen type I-coated CytoMatrix Cell Adhesion Strips (Chemicon International). The cells were incubated for $45 \mathrm{~min}$ in DMEM/F12 medium 
containing $1 \%$ charcoal-stripped fetal bovine serum with various concentrations of maslinic acid in the absence or presence of $10 \mathrm{ng} / \mathrm{ml} \mathrm{EGF}$. The strips were rinsed three times with PBS containing $\mathrm{Ca}^{2+} / \mathrm{Mg}^{2+}$ and stained for $5 \mathrm{~min}$ with $0 \cdot 2 \%$ crystal violet in $10 \%$ ethanol. The cell-bound stains were then quantified by determining the absorbance at $570 \mathrm{~nm}$. Cell viability was tested as described previously ${ }^{(27)}$.

\section{Gelatin zymography}

Cells were serum-starved in DMEM/F12 medium and treated with or without $10 \mathrm{ng} / \mathrm{ml} \mathrm{EGF}$ for $18 \mathrm{~h}$ in the absence or presence of maslinic acid. Conditioned media were collected, and the proteins were concentrated via centrifugal ultrafiltration using a Centricon Plus-20 filter (Millipore Corporation). Proteins in the concentrated media were separated by SDS-PAGE on a $7.5 \%$ acrylamide gel containing $1 \%$ gelatin. The volumes of media loaded onto the gel were adjusted to equivalent protein levels. After electrophoresis, the gels were washed twice with $2 \cdot 5 \%$ Triton X-100 for 30 min to completely eliminate SDS. The gels were then rinsed twice with zymogen activation buffer (50 mm-Tris- $\mathrm{HCl}, 0.02 \% \mathrm{Brij} 35,5 \mathrm{~mm}-\mathrm{CaCl}_{2}$ and $0.2 \mathrm{~mm}-\mathrm{NaCl}$ ) and incubated for $48 \mathrm{~h}$ at $37^{\circ} \mathrm{C}$ in the same buffer. The gels were subsequently stained with $0.25 \%$ Coomassie Brilliant Blue solution and destained. Serum-free conditioned medium from the HT-1080 human sarcoma cell line (American Type Culture Collection) was loaded on the gel as MMP-9 and MMP-2 controls.

\section{Western blot analyses}

Total cell lysates ${ }^{(28)}$ and nuclear extract ${ }^{(26)}$ were prepared as described previously. The protein contents were determined using a bicinchoninic acid protein assay kit (Thermo Scientific). Proteins in the total cell lysates, nuclear extract ( $50 \mu \mathrm{g}$ protein) and concentrated conditioned media (50 or $80 \mu \mathrm{g}$ protein) were analysed by Western blotting, as described previously ${ }^{(29)}$. The relative abundance of each band was quantified using the Bio-profile Bio-1D application (Vilber-Lourmat).

\section{Urokinase-type plasminogen activator activity}

uPA activity in conditioned media was estimated using a uPA activity kit (Millipore), according to the manufacturer's instructions.

\section{Real-time RT-PCR}

Total cellular RNA was isolated with an RNeasy Plus Mini kit (Qiagen) based on the manufacturer's protocol. Complementary DNA was synthesised using $3 \mu \mathrm{g}$ of isolated RNA and SuperScript II RT (Invitrogen), as described previously ${ }^{(26)}$. MMP-9, uPA, VEGF and HIF- $\alpha$ mRNA were quantified by RT-PCR using a Rotergene 3000 PCR apparatus (Corbett Research). Glyceraldehyde-3-phosphate dehydrogenase was used as the endogenous expression standard. Primer set sequences for real-time PCR amplification of MMP-9 ${ }^{(30)}, \mathrm{uPA}^{(30)}, \mathrm{VEGF}^{(30)}$, glyceraldehyde-3-phosphate dehydrogenase $\mathrm{s}^{(30)}$ and HIF- $\alpha^{(31)}$ were obtained from previously published work. PCR results were analysed and relative concentrations were calculated using Roter-gene software (version 6; Corbett), and the control levels $(0 \mu \mathrm{g} / \mathrm{l} \mathrm{EGF}+0 \mu \mathrm{m}$-maslinic acid) were set to 1 .

\section{Transfection and hypoxia-responsive element luciferase reporter assay}

The cells were co-transfected with the pGL3-Basic luciferase reporter vector (Promega) or the pGL3-hypoxia-responsive element (HRE)-luciferase reporter plasmid ${ }^{(32)}$ and the Renilla luciferase reporter vector (pRL-TK; Promega) using Nucleofector-II (Amaxa). Transfected cells were plated in twenty-four-well plates at 25000 cells/well. After $24 \mathrm{~h}$, cells were serum-deprived for $24 \mathrm{~h}$ and then incubated for $6 \mathrm{~h}$ with $0-25 \mu \mathrm{M}$-maslinic acid in the absence or presence of EGF. Luciferase activities were measured with the cell lysates using a dual luciferase assay system (Promega). HRE luciferase activity was normalised to Renilla luciferase activity.

\section{Statistical analysis}

Data are expressed as means with their standard errors and analysed with an ANOVA. Differences among the treatment groups were assessed by Duncan's multiple range test. Differences were considered significant at $P<0 \cdot 05$. All statistical analyses were performed using the SAS system for Windows version 9.1 (SAS Institute).

\section{Results}

\section{Maslinic acid inhibits the migration and invasion of} DU145 and TRAMP-C2 cells

To determine whether maslinic acid inhibits cell migration and invasion in DU145 cells, we cultured cells in the absence or presence of EGF, because we have previously demonstrated that EGF stimulates the migration, invasion and adhesion of DU145 cells ${ }^{(26)}$. Maslinic acid markedly inhibited both the basal and EGF-induced migration of DU145 cells (Fig. 1(A)). Maslinic acid also significantly inhibited the migration of TRAMP-C2 mouse prostate cancer cells (Fig. 1(C)). The transwell invasion assay was also conducted using Matrigel-coated filters, which demonstrated that maslinic acid concentrationdependently inhibited the basal and EGF-stimulated invasion of DU145 cells (Fig. 1(B)). As cell viability was not changed when the cells were treated for $18 \mathrm{~h}$ with $10-25 \mu \mathrm{M}$-maslinic acid (data not shown), we utilised $10-25 \mu \mathrm{mol} / 1$ of maslinic acid in the experiments.

\section{Maslinic acid alters the secretion of matrix metalloproteinase, tissue inhibitors of metalloproteinases and urokinase-type plasminogen activator in DU145 cells}

The gelatin zymography results revealed that EGF increased pro-MMP-9 (92 kDa) secretion, but that the maslinic acid treatment reduced pro-MMP-9 secretion in the absence and presence of EGF. Additionally, pro-MMP-2 ( $72 \mathrm{kDa}$ ) secretion increased with the EGF treatment but was reduced by maslinic 
(A)

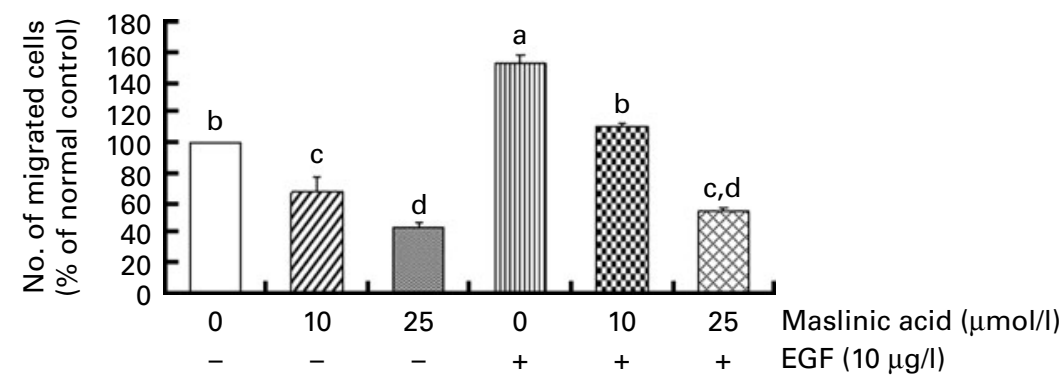

(B)

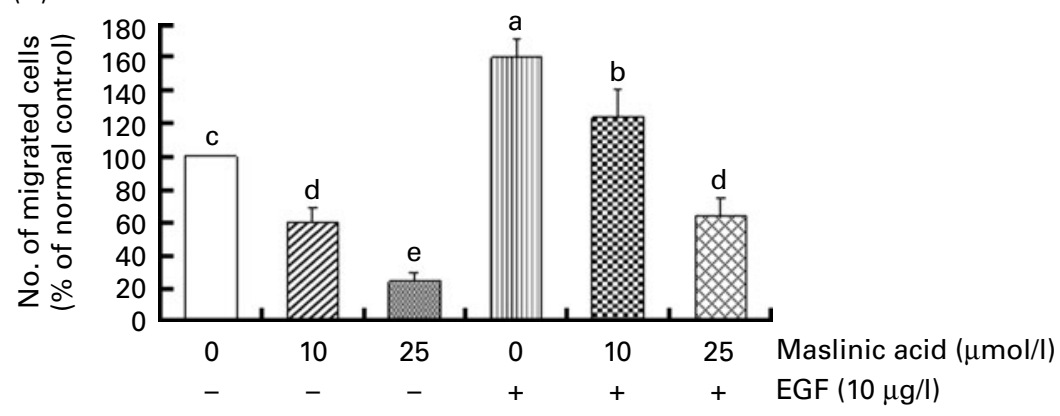

(C)

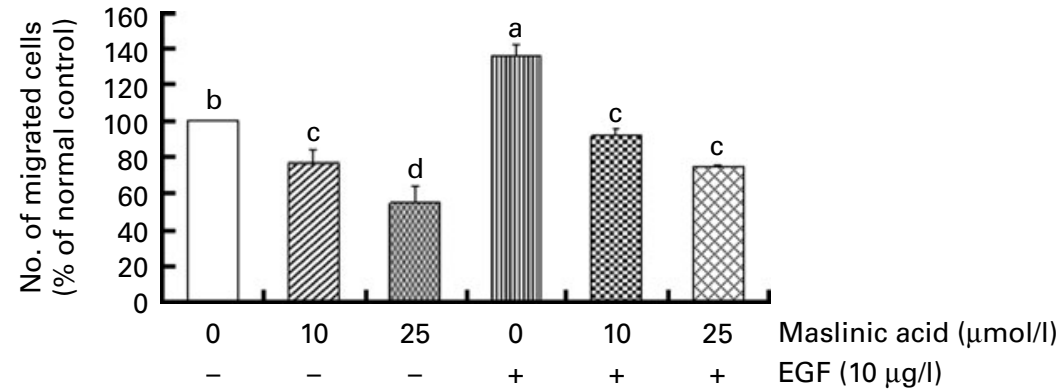

Fig. 1. Maslinic acid inhibits the migration and invasion of DU145 and TRAMP-C2 cells. Cells were serum-deprived in Dulbecco's modified Eagle's medium (DMEM)/nutrient mixture Ham's F12 (F12) containing 1\% charcoal-stripped fetal bovine serum (FBS) for 24h. (A, B) DU145 cells and (C) TRAM-C2 cells were plated on $6.5 \mathrm{~mm}$ transwell filters precoated with (A, C) type IV collagen or (B) Matrigel at 25000 cells/well and treated with $0-25 \mu \mathrm{M}-\mathrm{maslinic}$ acid. The lower compartment was filled with DMEM/F12 medium supplemented with $1 \%$ charcoal-stripped FBS and $0.1 \%$ bovine serum albumin with or without epidermal growth factor (EGF). Cells were incubated for (A) 4, (B) 12 or (C) $1 \mathrm{~h}$. (A, C) Migrating and (B) invading cells were quantified. Values are means from three independent experiments, with standard errors represented by vertical bars. ${ }^{\mathrm{a}, \mathrm{b}, \mathrm{c}, \mathrm{d}, \mathrm{e}}$ Mean values with unlike letters were significantly different $(P<0 \cdot 05)$.

acid, regardless of whether the cells were treated with EGF (Fig. 2(A)). The results from real-time RT-PCR analysis demonstrated that maslinic acid reduced MMP-9 mRNA levels, particularly in the presence of EGF (Fig. 2(B)). EGF stimulated the secretion of TIMP-1, and maslinic acid inhibited the secretion of the protein to an undetectable level in the absence or presence of EGF. TIMP-2 was not detected on the Western blot of DU145-conditioned medium either in the absence or presence of EGF. Maslinic acid dose-dependently increased TIMP-2 secretion (Fig. 2(C)). EGF increased pro- and active-uPA secretion, and maslinic acid markedly reduced the secretion of these proteins (Fig. 3(A)). uPA activity also increased with the EGF treatment but decreased with the maslinic acid treatment (Fig. 3(B)). Additionally, the levels of uPA transcripts increased with the EGF treatment but decreased with the maslinic acid treatment (Fig. 3(C)). Furthermore, the Western blot analysis of total cell lysates revealed that the UPAR protein levels were decreased significantly in cells treated with maslinic acid, regardless of whether they were treated with EGF or not. Plasminogen activator inhibitor-1 levels were not altered by either EGF or maslinic acid (Fig. 3(A)).

\section{Maslinic acid inhibits DU145 cell adhesion}

EGF increased DU145 cell adhesion to type I collagen, and maslinic acid inhibited basal and EGF-stimulated cell adhesion (Fig. 4(A)). The protein levels of ICAM and E-cadherin were not affected significantly by the EGF treatment, whereas they decreased following the maslinic acid treatment. However, the VCAM levels increased with the EGF treatment, but were inhibited by the maslinic acid treatment. The VCAM levels were not altered in cells treated with maslinic acid in the absence of EGF (Fig. 4(B)). 
Maslinic acid drastically inhibits vascular endothelial growth factor secretion in DU145 cells under both normoxic and hypoxic conditions

The Western blotting results demonstrated that VEGF secretion increased as a result of the EGF treatment and that maslinic acid inhibited VEGF secretion in the absence or presence of EGF with a normal oxygen supply (Fig. 5(A)). Additionally, VEGF mRNA levels changed in parallel with VEGF protein levels (Fig. 5(B)). Hypoxia significantly increased the VEGF levels, whereas maslinic acid markedly inhibited VEGF secretion under hypoxic conditions (Fig. 5(A)).
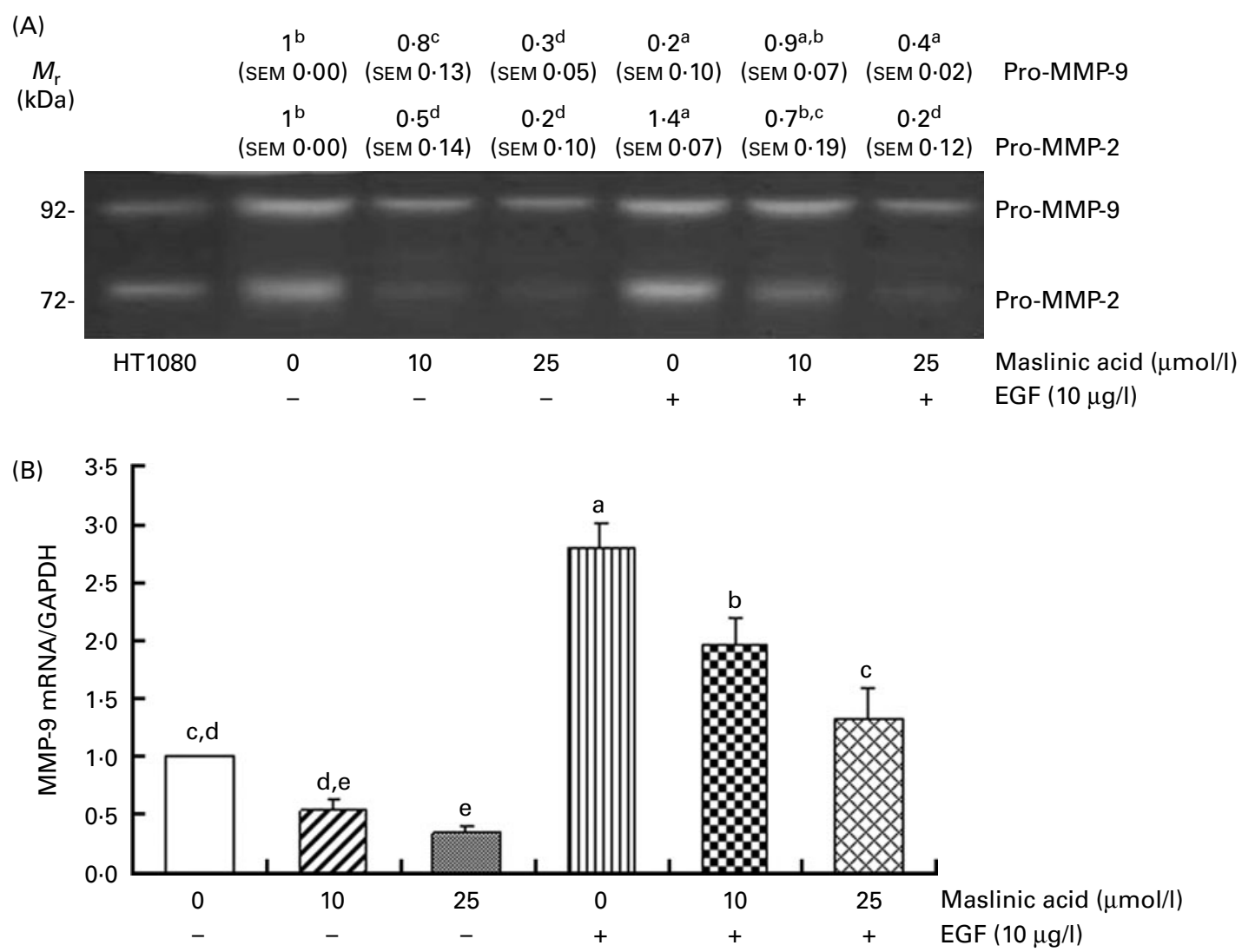

(C)

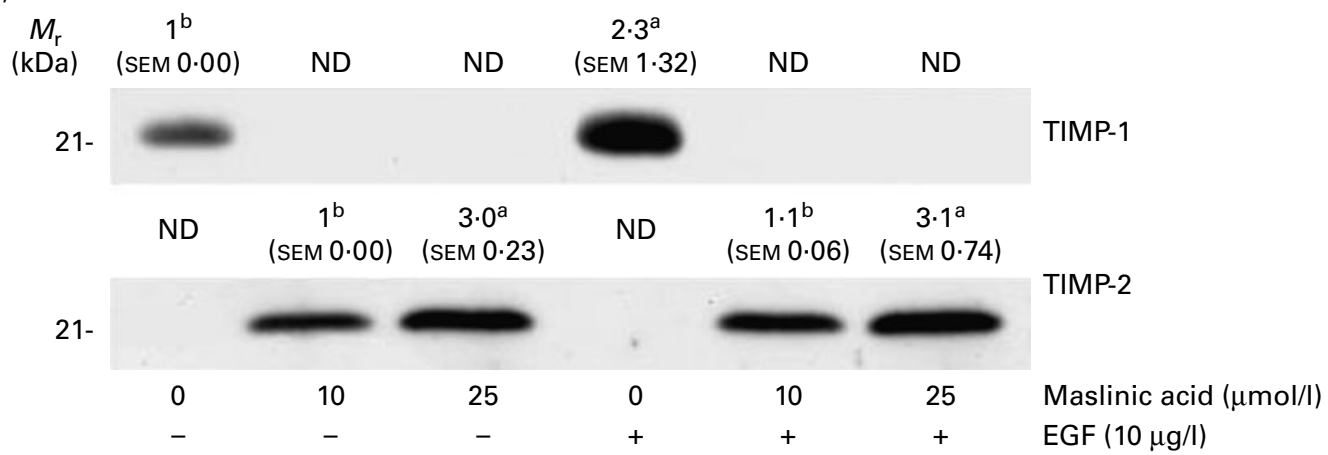

Fig. 2. Effect of maslinic acid on the secretion of matrix metalloproteinase (MMP) and tissue inhibitors of metalloproteinases (TIMP) in DU145 cells. DU145 cells were plated in $100 \mathrm{~mm}$ dishes at $2 \times 10^{6}$ cells/dish in Dulbecco's modified Eagle's medium (DMEM)/nutrient mixture Ham's F12 (F12) supplemented with $10 \%$ fetal bovine serum (FBS). At $1 \mathrm{~d}$ later, the monolayers were serum-deprived in DMEM/F12 medium containing $1 \%$ charcoal-stripped FBS for $24 \mathrm{~h}$. Cells were incubated with 0-25 mm-maslinic acid in serum-free medium with or without epidermal growth factor (EGF) for $18 \mathrm{~h}$. The $18 \mathrm{~h}$ conditioned media were concentrated for (A) gelatin zymography and (C) Western blotting. In the first lane of (A), serum-free HT-1080 cell-conditioned medium was loaded. The volumes of media loaded onto the gel were adjusted for equivalent protein concentrations. Photographs of chemiluminescent detection of Coomassie blue-stained (A) gels and (C) blots, which are representative of three independent experiments. The relative abundance of each band was quantified by densitometric scanning of the exposed film. The adjusted means of each band with their standard errors are shown above each blot. (B) Serum-deprived cells were incubated for $12 \mathrm{~h}$ with maslinic acid and/or EGF. Total RNA was isolated and reverse-transcribed, and real-time PCR was conducted. MMP-9 mRNA expression was normalised to that of glyceraldehyde-3-phosphate dehydrogenase (GAPDH). Values are means, with standard errors represented by vertical bars $(n 3)$. ${ }^{\text {,b,c,d,e }}$ Mean values with unlike letters were significantly different $(P<0.05)$. ND, not determined; $M_{\mathrm{r}}$, molecular weight. 
(A)
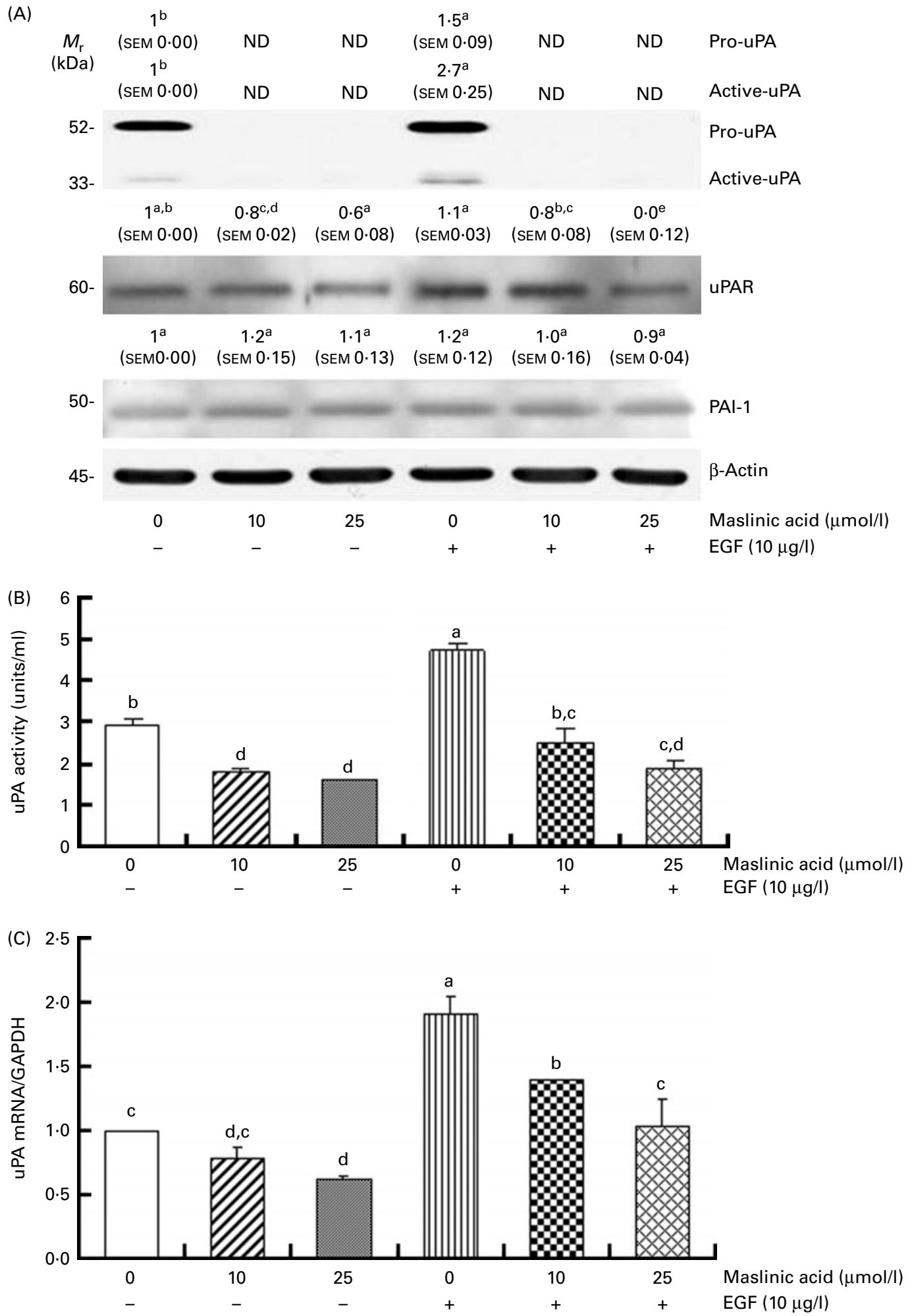

Fig. 3. Maslinic acid inhibits urokinase-type plasminogen activator (UPA) activity in DU145 cells. DU145 cells were plated, serum-deprived and treated with maslinic acid as described in Fig. 2, and $18 \mathrm{~h}$ conditioned media were collected. (A) To determine uPA secretion and uPA receptor (UPAR) expression, volumes of media and total cell lysates, respectively, loaded onto the gel were adjusted for equivalent protein concentrations. Photographs of chemiluminescent detection of the Western blots, which are representative of three independent experiments, are shown. The relative abundance of each band was quantified by densitometric scanning of the exposed film. uPAR and plasminogen activator inhibitor 1 (PAI-1) levels were normalised to those of $\beta$-actin. The adjusted means of each band with their standard errors are shown above each blot. (B) UPA activity was with unlike letters determined using unconcentrated conditioned media. (C) Serumdeprived cells were incubated with maslinic acid and/or epidermal growth factor (EGF) for $12 \mathrm{~h}$. Total RNA was isolated and reverse-transcribed, and real-time PCR was conducted. The levels of uPA mRNA were normalised to those of glyceraldehyde-3-phosphate dehydrogenase (GAPDH). Values are means, with standard errors represented by vertical bars $(n 3)$. ${ }^{\mathrm{a}, \mathrm{b}, \mathrm{c}, \mathrm{d}, \mathrm{e}}$ Mean values were significantly different $(P<0.05)$. ND, not determined; $M_{\mathrm{r}}$, molecular weight. 


\section{Maslinic acid reduces hypoxia-inducible factor- $1 \alpha$ levels} in DU145 cells

Because HIF- $1 \alpha$ is a transcription factor that induces VEGF, MMP, uPAR and E-cadherin expression ${ }^{(23)}$, we determined the effect of maslinic acid on HIF- $1 \alpha$ levels in DU145 cells under both normoxic and hypoxic conditions. The Western blot analysis of total cell lysates revealed that HIF-1 $\alpha$ levels increased markedly under hypoxic condition. EGF increased HIF-1 $\alpha$ expression under both normoxic and hypoxic conditions, whereas maslinic acid drastically inhibited HIF- $1 \alpha$ expression with or without EGF under both conditions
(Fig. 6(A)). Moreover, HIF-1 $\alpha$ levels in the nucleus were substantially lower in cells treated with maslinic acid (Fig. 6(B)). The results from HRE-driven luciferase reporter gene assays revealed that EGF increased HRE luciferase activity, whereas maslinic acid reduced its activity in a concentration-dependent fashion under both the basal and EGF-induced conditions (Fig. 6(C)). We conducted real-time PCR assays to determine whether maslinic acid regulates HIF-1 $\alpha$ levels at the mRNA level. HIF- $1 \alpha$ mRNA levels increased with EGF but decreased with the maslinic acid treatment (Fig. 6(D)). To determine whether the maslinic acid treatment affects HIF- $1 \alpha$ protein stability, DU145 cells were treated with or without maslinic

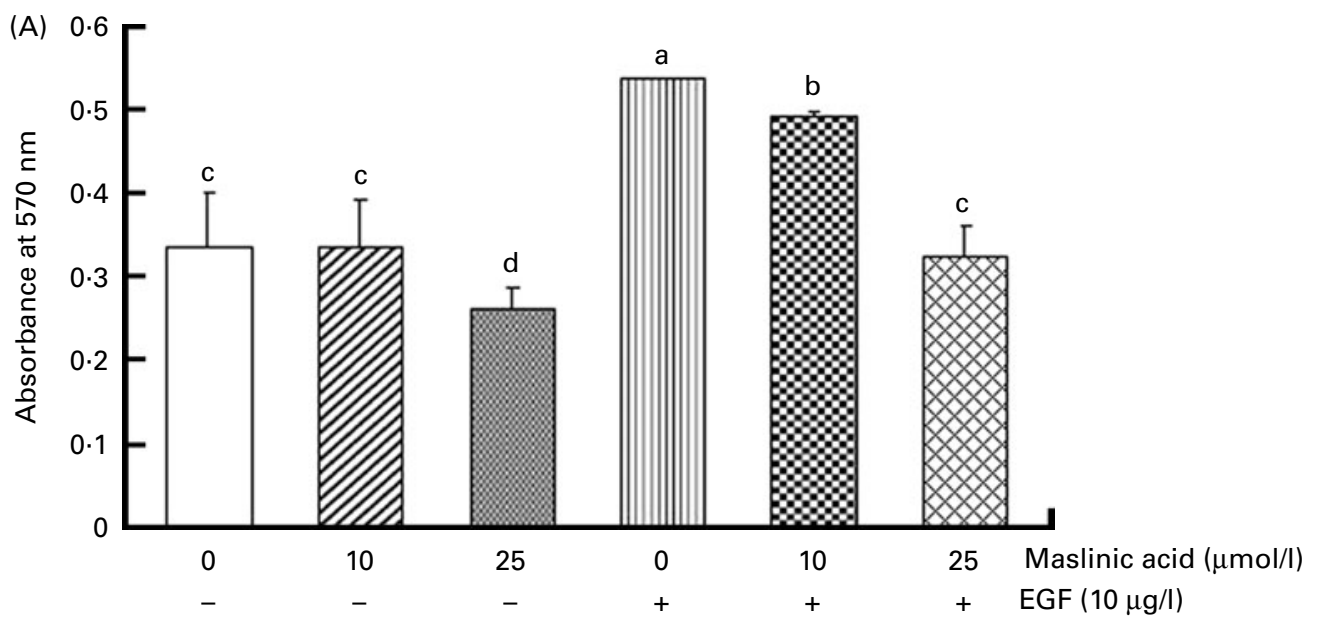

(B) $\begin{array}{lllllll}M_{\mathrm{r}} & 1^{\mathrm{a}} & 0.7^{\mathrm{b}} & 0.6^{\mathrm{b}} & 0.9^{\mathrm{a}} & 0.7^{\mathrm{b}} & 0.6^{\mathrm{b}}\end{array}$

$\begin{array}{lllll}\text { (kDa) (SEM 0.00) (SEM 0.06) (SEM 0.07) (SEM 0.01) (SEM 0.09) (SEM 0.04) } & \text { (SE }\end{array}$

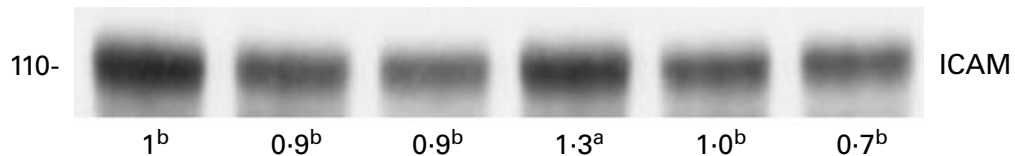

(SEM 0.00) (SEM 0.12) (SEM 0.13) (SEM 0.14) (SEM 0.11) (SEM 0.06)

$110-$
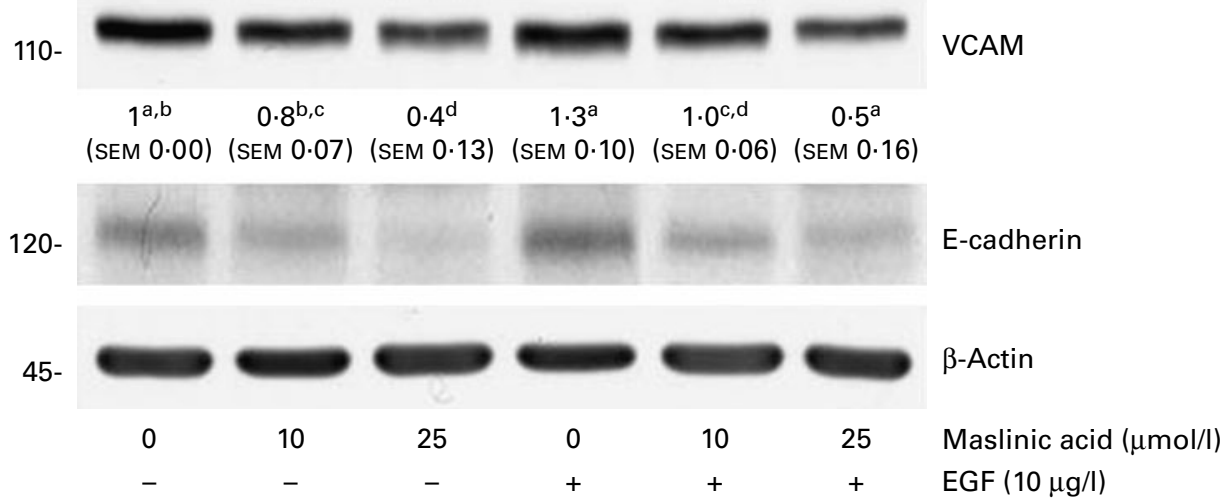

Fig. 4. Maslinic acid inhibits adhesion of DU145 cells. (A) Serum-deprived DU145 cells were plated in CytoMatrix ${ }^{\mathrm{TM}}$ human collagen I cell adhesion strips (Chemicon International) and were incubated for 45 min in Dulbecco's modified Eagle's medium/nutrient mixture Ham's F12 containing $1 \%$ charcoal-stripped fetal bovine serum with $0-25 \mu \mathrm{M}$-maslinic acid with or without epidermal growth factor (EGF). Cells were stained with $0.2 \%$ crystal violet, and the cell-bound stains were quantified colorimetrically. Values are means, with standard errors represented by vertical bars $(n 4)$. (B) Serum-deprived DU145 cells were treated with maslinic acid in serum-deprived media. Total cell lysates were subjected to immunoblotting with antibodies raised against intercellular adhesion molecule (ICAM), vascular cell adhesion molecule (VCAM) or E-cadherin. Photographs of chemiluminescent detection of the blots, which are representative of three independent experiments, are shown. The relative abundance of each band was estimated by densitometric scanning of the exposed films, and the expression levels were normalised to those of $\beta$-actin. The adjusted means $(n 3)$ of each band with their standard errors are shown above each blot. ${ }^{a, b, c, d}$ Mean values with unlike letters were significantly different $(P<0.05)$. $M_{\mathrm{r}}$, molecular weight. 
acid in the presence of $100 \mu \mathrm{m}$-cycloheximide, which inhibits new cellular protein synthesis. The HIF-1 $\alpha$ protein decayed with a half-life of $11.81 \mathrm{~min}$ in the absence of maslinic acid, whereas the half-life decreased to $4.96 \mathrm{~min}$ when cells were treated with maslinic acid (Fig. 6(E)).

\section{Maslinic acid inhibits Akt and extracellular signal-related kinase 1/2 phosphorylation}

We next examined whether maslinic acid inhibits basal and EGF-stimulated Akt and ERK1/2 phosphorylation in DU145 cells. Treating DU145 cells with EGF for 15 min induced Akt and ERK1/2 phosphorylation, but maslinic acid significantly reduced the levels of phospho-Akt and ERK1/2 (Fig. 7(A)). To examine whether inhibiting Akt and ERK1/2 activation would reduce HIF-1 $\alpha$ levels and VEGF secretion in DU145 cells, we treated the cells with the phosphatidylinositol 3kinase inhibitor LY294002 or the ERK-specific inhibitor PD98509. LY294002 and PD98509 inhibited basal and EGFinduced Akt and ERK1/2 phosphorylation, respectively. These two inhibitors reduced the cellular levels of HIF-1 $\alpha$ and the secretion of VEGF in DU145 cells (Fig. 7(B) and (C)).

\section{Discussion}

We have shown that maslinic acid, a natural triterpenoid present in pomace olive oil, inhibited basal and EGF-induced migration, invasion and adhesion in DU145 prostate cancer cells. We also demonstrated that treating DU145 cells with maslinic acid resulted in (1) a decreased secretion of MMP-2, MMP-9, TIMP-1 and UPA and increased TIMP-2 secretion; (2) a decreased expression of E-cadherin, UPAR, ICAM and VCAM; (3) decreased uPA activity; (4) decreased VEGF secretion under both hypoxic and normoxic conditions; (5) decreased cellular HIF- $1 \alpha$ levels under both hypoxic and normoxic conditions; (6) decreased HIF-1 $\alpha$ transcripts, nuclear HIF-1 $\alpha$ levels, HRE reporter activity and HIF- $1 \alpha$ stability; and (7) a decreased activation of Akt and ERK1/2. Furthermore, we have shown that inhibiting Akt and ERK1/2 activation induced a reduction in HIF- $1 \alpha$ levels and VEGF secretion. These results indicate that maslinic acid inhibited Akt and ERK1/2 activation, which, in turn, reduced HIF- $1 \alpha$ activity, thereby resulting in the inhibited expression of genes involved in the stimulation of tumour angiogenesis and metastasis.

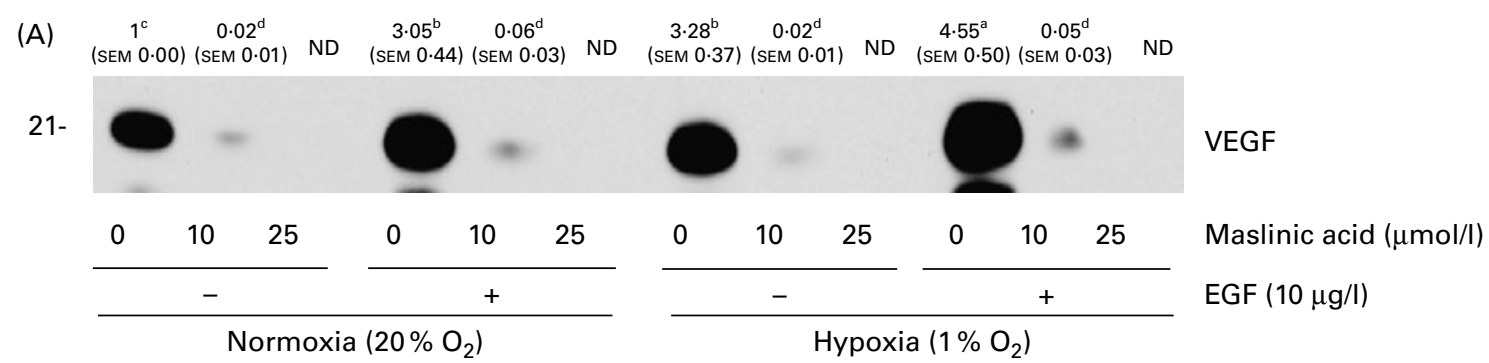

(B)

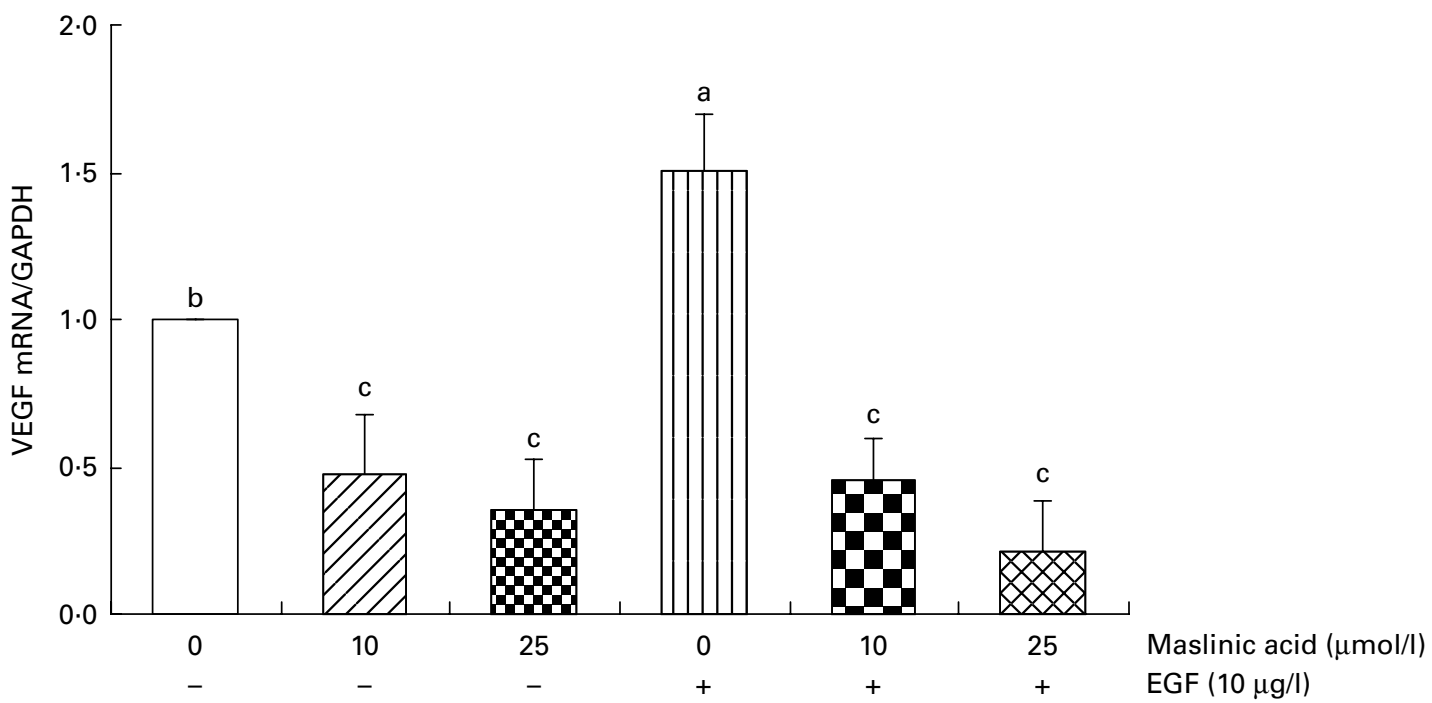

Fig. 5. Maslinic acid inhibits vascular endothelial growth factor (VEGF) secretion in DU145 cells. DU145 cells were plated and serum-deprived as described in Fig. 2. (A) Serum-deprived cells were treated with $0-25 \mu \mathrm{M}$-maslinic acid for $18 \mathrm{~h}$ in serum-free media with or without epidermal growth factor (EGF) under normoxic or hypoxic conditions. The $18 \mathrm{~h}$ conditioned media were concentrated for Western blotting. The volumes of media loaded onto the gel were adjusted for equivalent protein concentrations. Photographs of chemiluminescent detection of the blots, which are representative of three independent experiments, are shown. The relative abundance of each band was quantified by densitometric scanning of the exposed films, and the adjusted means of each band with their standard errors are shown above each blot. (B) Serum-deprived cells were treated with maslinic acid and/or EGF for $12 \mathrm{~h}$. Total RNA was isolated for real-time PCR. The levels of VEGF mRNA were normalised to those of glyceraldehyde-3-phosphate dehydrogenase (GAPDH). Values are means ( $n$ 3), with standard errors represented by vertical bars. ${ }^{a, b, c, d}$ Mean values with unlike letters were significantly different $(P<0.05)$. ND, not determined. 


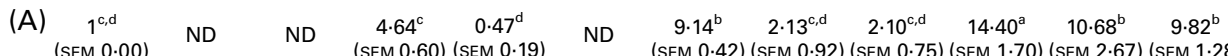

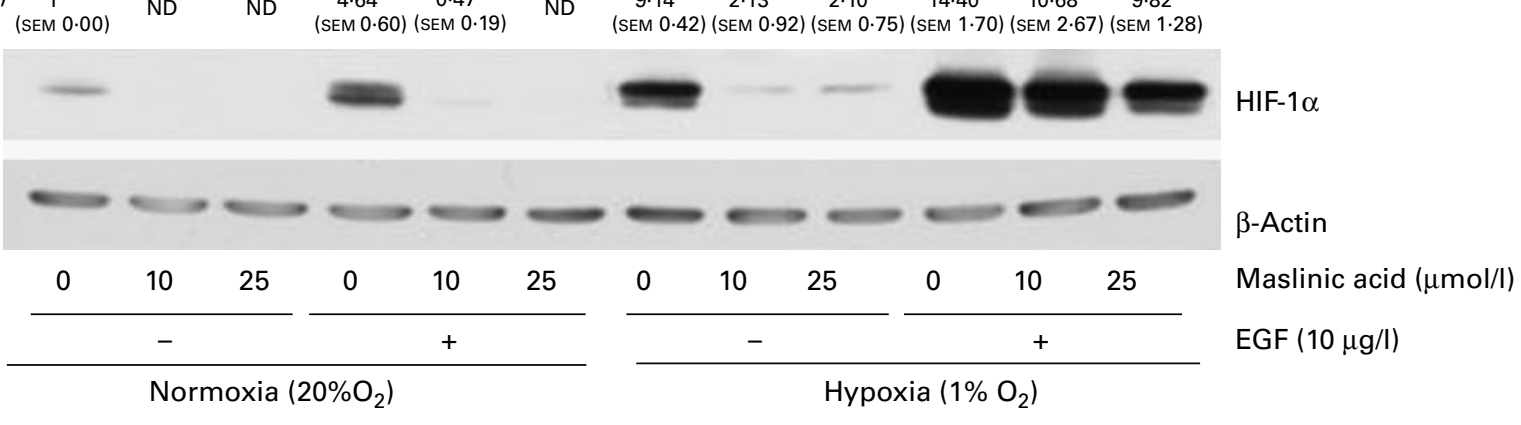

(B)

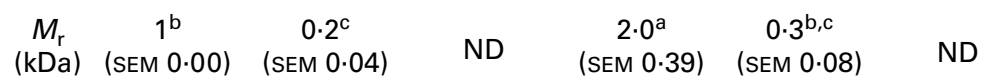

$120-$

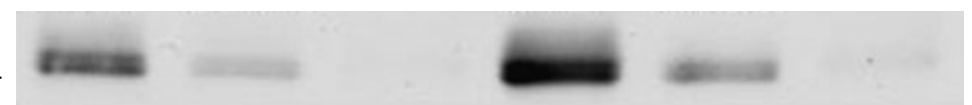

HIF-1 $\alpha$ (nuclear)

42-

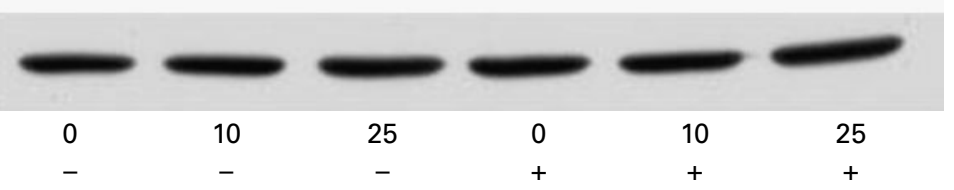

$\beta$-Actin (nuclear)

Maslinic acid $(\mu \mathrm{mol} / \mathrm{l})$ EGF $(10 \mu \mathrm{g} / \mathrm{l})$
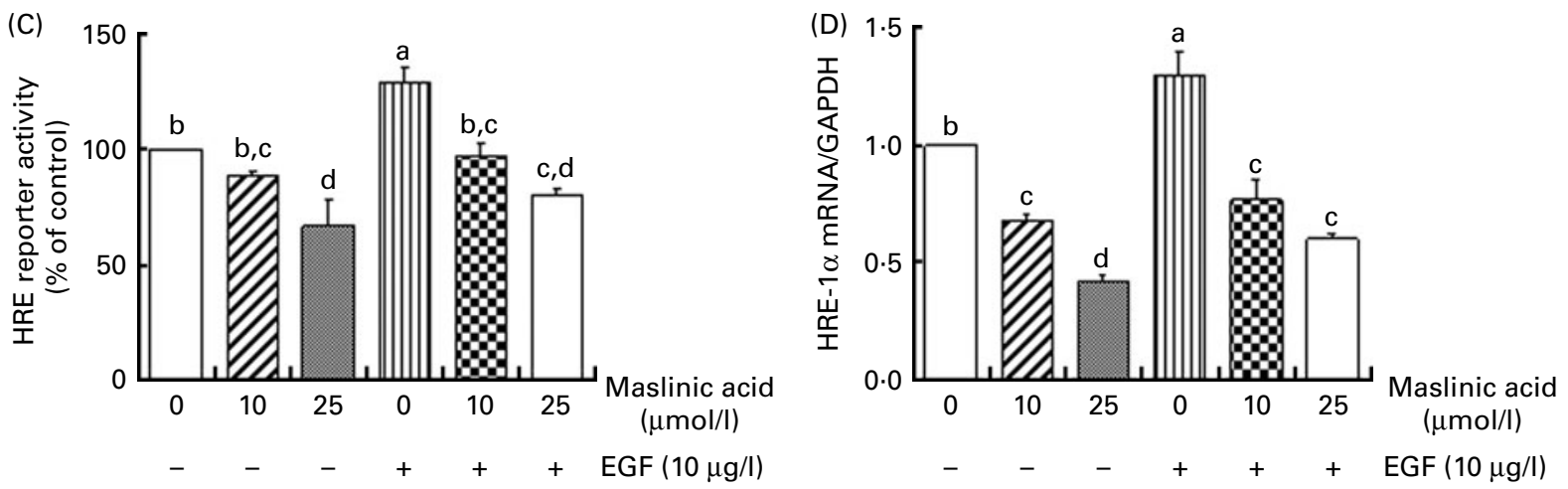

(E) Time (min) $0 \quad 5 \quad 10 \quad 20 \quad 30$

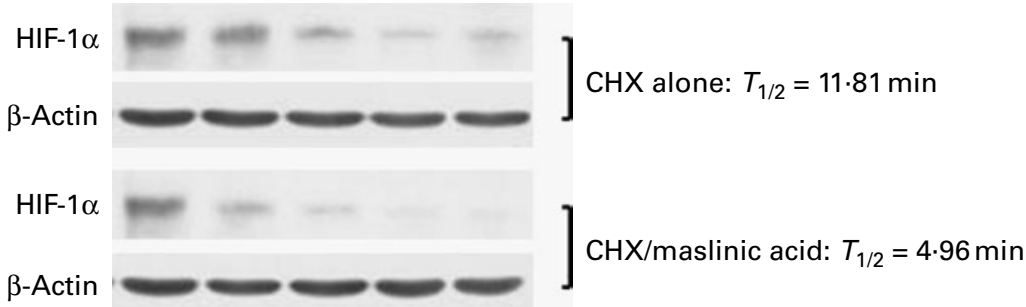

Fig. 6. Maslinic acid reduces hypoxia-inducible factor (HIF)-1 $\alpha$ protein levels in DU145 cells. (A, B) Serum-deprived cells were incubated with 0-25 $\mu$ M-maslinic acid in serum-deprived media with or without epidermal growth factor (EGF) for $6 \mathrm{~h}$ under normoxic or hypoxic conditions. (E) Serum-deprived cells were stimulated with EGF for $6 \mathrm{~h}$ and then treated with $100 \mu \mathrm{M}$-cycloheximide (CHX) with or without $10 \mu \mathrm{M}$-maslinic acid for the indicated periods. Total cell lysates (A, E) and the nuclear fractions (B) were subjected to Western blotting with an HIF-1 $\alpha$ antibody. The relative abundance of each band was quantified by densitometric scanning of the exposed films, and the expression levels were normalised to those of $\beta$-actin. The adjusted means of each band with their standard errors are shown above each blot. (C) Cells were co-transfected with a human hypoxia-responsive element (HRE) reporter gene construct and a pRL-TK control vector. The transfected cells were plated in twenty-four-well plates at 25000 cells/well. After serum deprivation, cells were incubated with the indicated concentrations of maslinic acid in serumdeprived media with or without EGF for $6 \mathrm{~h}$. Cell lysates were prepared to measure luciferase and Renilla activities. Luciferase activity was normalised to Renilla activity. (D) Serum-deprived cells were incubated for $12 \mathrm{~h}$ with maslinic acid and/or EGF. Total RNA was isolated and reverse-transcribed, and real-time PCR was conducted. HIF-1 $\alpha$ mRNA expression was normalised to that of glyceraldehyde-3-phosphate dehydrogenase (GAPDH). Values are means ( $n 3$ ), with standard errors represented by vertical bars. ${ }^{\mathrm{a}, \mathrm{b}, \mathrm{c}, \mathrm{d}}$ Mean values with unlike letters were significantly different $(P<0.05)$. ND, not determined; $M_{\mathrm{r}}$, molecular weight. 
(A)

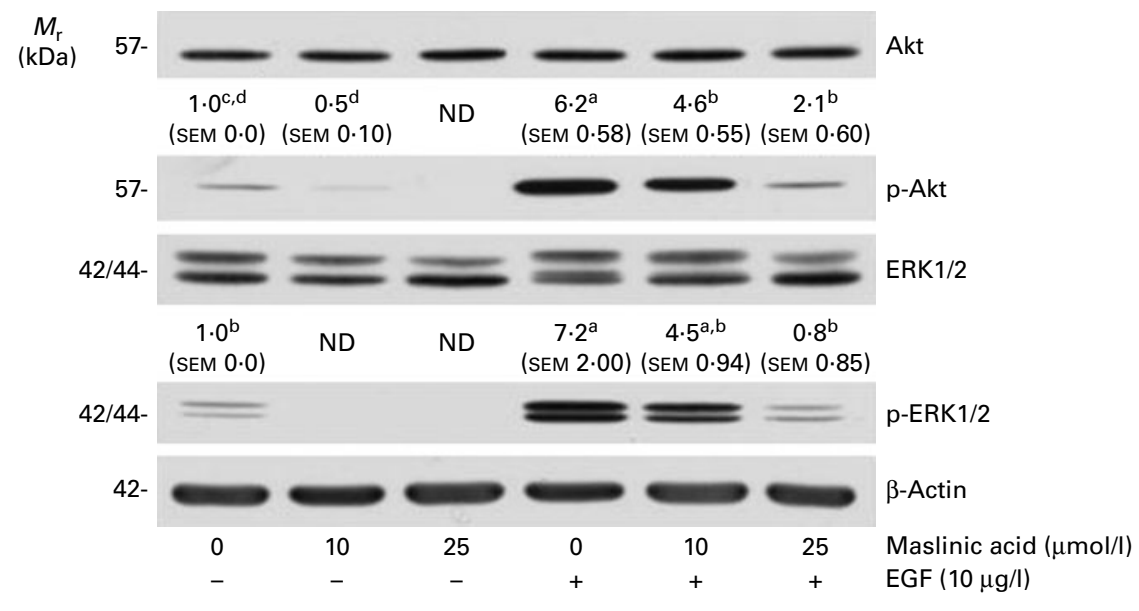

(B) $\quad \begin{array}{llllll}1.0^{\mathrm{b}} & 0.2^{\mathrm{d}} & 0.1^{\mathrm{d}} & 2.5^{\mathrm{a}} & 0.7^{\mathrm{c}} & 0.1^{\mathrm{d}}\end{array}$

(SEM 0.00) (SEM 0.02) (SEM 0.02) (SEM 0.24) (SEM 0.04) (SEM 0.02)

$57-$

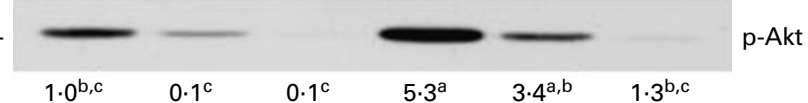

(SEM 0.00) (SEM 0.16) (SEM 0.07) (SEM 1.56) (SEM 0.62) (SEM 0.67)

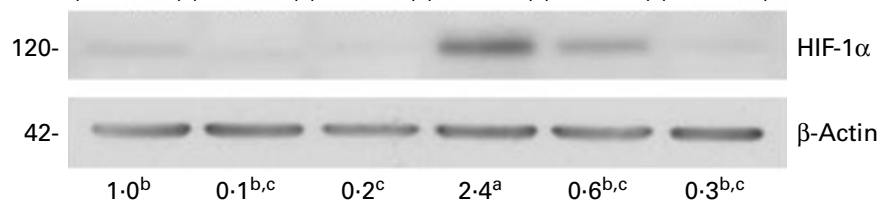

(SEM 0.00) (SEM 0.08) (SEM 0.02) (SEM 0.51) (SEM 0.15) (SEM 0.04)

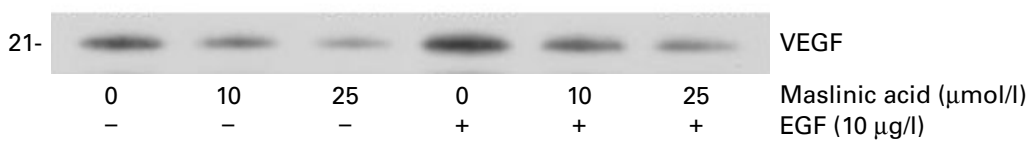

(C)

$\begin{array}{llllll}1.0^{\mathrm{c}} & 0.1^{\mathrm{d}} \quad 0.2^{\mathrm{d}} \quad 2.3^{\mathrm{a}} \quad 0.6^{\mathrm{b}} \quad 0.3^{\mathrm{b}}\end{array}$

(SEM 0.00) (SEM 0.09) (SEM 0.08) (SEM 0.17) (SEM 0.16) (SEM 0.19)

42/44-

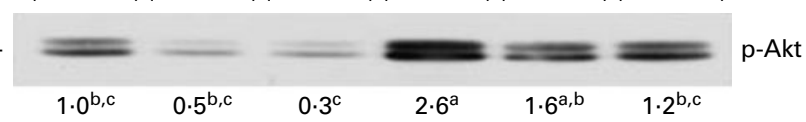

(SEM 0.00) (SEM 0.15) (SEM 0.14) (SEM 0.74) (SEM 0.28) (SEM 0.29)

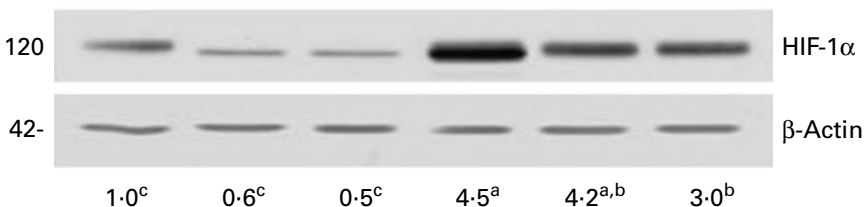

(SEM 0.00) (SEM 0.02) (SEM 0.05) (SEM 0.48) (SEM 0.60) (SEM 0.47)

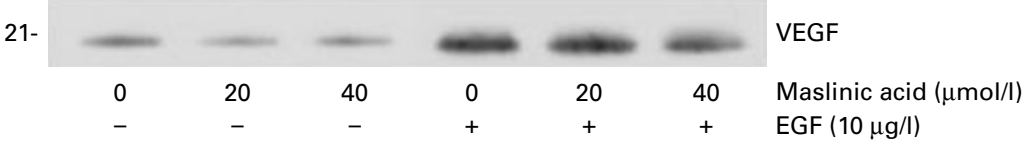

Fig. 7. Maslinic acid reduces the activation of Akt and extracellular signal-related kinase (ERK) in DU145 cells. (A) Serum-deprived cells were incubated with $0-$ $25 \mu \mathrm{M}$-maslinic acid for $6 \mathrm{~h}$, and cell lysates were prepared with or without a $15 \mathrm{~min}$ epidermal growth factor (EGF) stimulation. Serum-deprived cells were incubated with (B) 0-20 $\mu \mathrm{M}$-LY294002 or (C) 0-40 $\mu \mathrm{M}$-PD98059 for $6 \mathrm{~h}$ and lysed without stimulation or after 15 min of EGF stimulation to determine phospho (p)-Akt or p-ERK1/2 levels. To identify hypoxia-inducible factor-1 $\alpha$ (HIF-1 $\alpha$ ), serum-deprived cells were incubated with (B) 0-20 $\mu M-L Y 294002$ or (C) 0-40 $\mu M-P D 98059$ in the absence or presence of EGF for $6 \mathrm{~h}$. Total cell lysates were subjected to Western blotting. Photographs of chemiluminescent detection of the blots, which are representative of three independent experiments, are shown. The relative abundance of each band was estimated by densitometric scanning of the exposed films, and the expression levels were normalised to those of $\beta$-actin. To determine vascular endothelial growth factor (VEGF) concentrations, serum-deprived cells were incubated with (B) 0-20 $\mu \mathrm{M}-\mathrm{LY} 294002$ or (C) 0-40 $\mu \mathrm{M}$-PD98059 in serum-free media with or without $10 \mu \mathrm{g} / \mathrm{l}$ EGF for $18 \mathrm{~h}$. The $18 \mathrm{~h}$ conditioned media were concentrated and subjected to Western blotting with VEGF antibody. The volumes of media loaded onto the gel were adjusted for equivalent protein concentrations. Photographs of chemiluminescent detection of the blots, which are representative of three independent experiments, are shown. The relative abundance of each band was quantified by densitometric scanning of the exposed films. The adjusted means $(n 3)$ of each band with their standard errors are shown above each blot. ${ }^{\mathrm{a}, \mathrm{b}, \mathrm{c}, \mathrm{d}}$ Mean values with unlike letters were significantly different $(P<0.05)$. $M_{\mathrm{r}}$, molecular weight. 
Metastasis has been described as a two-phase process: (1) physical translocation of a cancer cell to a distant organ and (2) colonisation of the translocated cells at that distant site $^{(33)}$. To begin the metastatic cascade, cancer cells within the primary tumour must break away from their neighbours, push their way through the surrounding stroma and break through the basement membrane to enter the circulation. These steps are required for several proteolytic enzymes to degrade the extracellular matrix, which includes interstitial collagens, basement membrane collagen (type IV), fibronectin, laminin and various proteoglycans ${ }^{(34)}$. MMP and uPA are important proteases involved in extracellular matrix degradation $^{(10,11)}$. Maslinic acid markedly reduced the secretion of MMP and UPA as well as UPA activity and UPAR expression, and increased TIMP-2 (Figs. 2 and 3), which probably contributed to the decreased invasion and migration of DU145 cells. Additionally, we observed that maslinic acid inhibited DU145 cell adhesion, which was accompanied by decreases in the levels of E-cadherin, ICAM and VCAM (Fig. 4). Among the many changes inherent to the tumour progression process, alterations in cell-cell and cell-matrix adhesion appear to play a crucial role in promoting tumour cell invasion, migration and metastasis ${ }^{(35)}$. The present results indicate that decreases in these adhesion-regulating molecules contributed to maslinic acid-induced decreases in DU145 cell adhesion.

As invasive solid tumours suffer from intratumoral hypoxia resulting from an abnormality in the microvasculature and the rapid expansion of tumour mass ${ }^{(36)}$, angiogenesis is critical for tumour survival and growth. VEGF stimulates angiogenesis by activating a group of signalling pathways that stimulate the growth, migration and survival of endothelial cells, vascular permeability, and the mobilisation of endothelial precursor cells from the bone marrow into the general circulation ${ }^{(24)}$. A natural compound that inhibits VEGF production has potential for use as a next-generation cancer prevention agent. In the present study, maslinic acid significantly inhibited basal and EGF-induced VEGF production in DU145 cells under both normoxic and hypoxic conditions (Fig. 5). When the present study was in progress, Li et al. ${ }^{(37)}$ reported that maslinic acid inhibited VEGF and UPA secretion and HIF- $1 \alpha$ mRNA expression in liver cancer cells. Together, these results suggest that maslinic acid could be used as an anti-angiogenic agent to prevent liver and prostate cancer.

When tumour cells are exposed to hypoxic stress, the transcriptional activity of HIF-1 increases and plays an important role in promoting cancer angiogenesis and anaerobic metabolism $^{(22)}$. HIF-1 is a well-established transcriptional regulator of VEGF and of many other genes involved in tumour growth and angiogenesis. In addition to HIF- $1 \alpha$ regulation by hypoxia, HIF-1 $\alpha$ can be activated in tumours under normoxic conditions as a result of genetic alterations affecting key oncogenes and tumour-suppressor genes ${ }^{(23,38,39)}$. The present results demonstrate that maslinic acid reduced HIF$1 \alpha$ protein levels under normoxic and hypoxic conditions in DU145 cells (Fig. 6(A)). Additionally, maslinic acid decreased HIF-1 $\alpha$ transcripts and increased HIF-1 $\alpha$ degradation (Fig. 6(D)). Taken together, these results suggest that maslinic acid reduced HIF- $\alpha$ levels by reducing transcript levels and protein stability. However, the effect of maslinic acid on the synthesis and degradation of HIF- $\alpha$ mRNA and protein synthesis needs to be examined in the future.

Maslinic acid reduced the nuclear levels of HIF-1 $\alpha$ (Fig. 6(B)) and HRE reporter activities (Fig. 6(C)) in DU145 cells, demonstrating that maslinic acid reduced HIF-1 transcriptional activity. HIF- $1 \alpha$ can directly activate the expression of a variety of pro-angiogenic and pro-metastatic factors, including VEGF, VEGF receptors, E-cadherin, plasminogen activator inhibitor-1, UPAR, MMP-2 and MMP-9 ${ }^{(23,25)}$. In the present study, maslinic acid significantly reduced VEGF, MMP-2, MMP-9, uPA, UPAR and E-cadherin protein and/or mRNA levels in DU145 cells (Figs. 2, 3 and 5). These findings indicate that maslinic acid exhibits antiangiogenic and antimetastatic effects under normoxic and hypoxic conditions by inhibiting HIF- $1 \alpha$ activity.

The HIF-1 $\alpha$ subunit is regulated by several signalling pathways, including phosphoinositol 3-kinase/Akt and mitogenactivated protein kinases, in response to various hormones, growth factors, cytokines, oncogenes and hypoxia (reviewed in Dimova et $a l^{\left({ }^{(40)}\right)}$. It has been reported that Akt and ERK1/2 signalling plays a role in HIF- $1 \alpha$ expression in breast $^{(41)}$ and prostate ${ }^{(42,43)}$ cancer cells. We found that maslinic acid inhibited basal and EGF-induced Akt and ERK1/2 phosphorylation in DU145 cells (Fig. 7(A)). Additionally, inhibiting Akt and ERK1/2 activation by specific inhibitors reduced cellular HIF-1 $\alpha$ levels and VEGF secretion (Fig. 7(B) and (C)). Taken together, these results suggest that maslinic acid inhibited Akt and ERK signalling, which in turn reduced HIF-1 $\alpha$ activity and thereby reduced VEGF secretion. As maslinic acid inhibited EGF-induced ERK1/2 and Akt activation, future studies are needed to determine whether maslinic acid inhibits various growth factor signalling pathways.

In the present in vitro study, we demonstrated that maslinic acid inhibits the metastatic capacity of DU145 cells at 10$25 \mu \mathrm{mol} / \mathrm{l}$. To the best of our limited knowledge, nutritional relevance of the concentrations of maslinic acid has yet to be elucidated. The concentration of maslinic acid in virgin olive oils has been reported to vary from 3.93 to $41.81 \mathrm{mg} / \mathrm{kg}^{(44)}$. Additionally, the concentration of maslinic acid increases as olive oil quality decreases $(38 \mathrm{mg} / \mathrm{kg}$ for extra virgin and $721 \mathrm{mg} / \mathrm{kg}$ for crude pomace olive oils ${ }^{(45,46)}$. The intake of olive oil in the Mediterranean countries is estimated to be $30-50 \mathrm{~g} / \mathrm{d}^{(47)}$. Vissers et al. $^{(47)}$ estimated that the plasma concentration of phenols with antioxidant potential resulting from the intake of $50 \mathrm{~g}$ olive oil can be at most $0.06 \mu \mathrm{mol} / \mathrm{l}$, which is much lower than the concentrations of these phenols (10-25 $\mu \mathrm{mol} / \mathrm{l})$ required to show anti-metastatic activity in vitro. Thus, it appears that the concentrations of maslinic acid utilised in the present in vitro study are difficult to achieve in human subjects by dietary intake of olive oils. However, an in vivo study utilising a xenograft mouse model has shown that subcutaneous injection of $10-50 \mathrm{mg} / \mathrm{kg}$ body weight of maslinic acid every $2 \mathrm{~d}$ drastically suppressed pancreatic tumour growth $^{(37)}$. Nevertheless, there has been no study that investigated the concentrations and distributions of maslinic acid in various tissues of animals and human subjects after the administration of maslinic acid. Future in vivo studies in 
animals and human subjects are needed to determine whether maslinic acid can be developed as a chemopreventive and/or chemotherapeutic agent.

In conclusion, we demonstrated that maslinic acid suppressed HIF-1 $\alpha$ expression by inhibiting Akt and ERK1/2 activation and suppressed the expression of VEGF, MMP, UPA, uPAR, E-cadherin, ICAM and VCAM in DU145 cells. Because HIF- $1 \alpha$ regulates a number of genes that stimulate angiogenesis and metastasis, it is possible that maslinic acid could be useful as an angiogenesis and metastasis inhibitor. Future animal studies are warranted to determine whether maslinic acid inhibits tumour angiogenesis and metastasis in vivo.

\section{Acknowledgements}

The present study was supported by the Mid-career Researcher Program (grant no. 2010-0006923), the SRC program (Center for Food and Nutritional Genomics: grant no. 2011-0000912) and the Leap Research Program (20100029233) of the National Research Foundation of Korea, funded by the Ministry of Education, Science and Technology. S. Y. P., C. W. N., D. Y. K., Y.-H. K., K. W. L and J. H. Y. P. designed the experiments. S. Y. P. conducted the biochemical analyses and analysed the data. S. Y. P. wrote the first draft of the manuscript. J. H. Y. P. revised the manuscript. All authors read and approved the final manuscript. The authors declare that they have no conflict of interest.

\section{References}

1. Greenlee RT, Hill-Harmon MB, Murray T, et al. (2001) Cancer statistics, 2001. CA Cancer J Clin 51, 15-36.

2. Lu C, Williams AK, Chalasani V, et al. (2011) Immunotherapy for metastatic prostate cancer: where are we at with sipuleucel-T? Expert Opin Biol Ther 11, 99-108.

3. Sharma S, Shin JS, Grimshaw M, et al. (2010) The senescence pathway in prostatic carcinogenesis. Pathology 42, 507-511.

4. Thompson IM, Tangen CM, Klein EA, et al. (2005) Phase III prostate cancer prevention trials: are the costs justified? J Clin Oncol 23, 8161-8164.

5. Shukla S \& Gupta S (2005) Dietary agents in the chemoprevention of prostate cancer. Nutr Cancer 53, 18-32.

6. Reyes FJ, Centelles JJ, Lupianez JA, et al. (2006) (2Alpha,3beta)-2,3-dihydroxyolean-12-en-28-oic acid, a new natural triterpene from Olea europaea, induces caspase dependent apoptosis selectively in colon adenocarcinoma cells. FEBS Lett 580, 6302-6310.

7. Reyes-Zurita FJ, Rufino-Palomares EE, Lupianez JA, et al. (2009) Maslinic acid, a natural triterpene from Olea europaea L. induces apoptosis in HT29 human colon-cancer cells via the mitochondrial apoptotic pathway. Cancer Lett $\mathbf{2 7 3}$, $44-54$.

8. Martin R, Carvalho-Tavares J, Ibeas E, et al. (2007) Acidic triterpenes compromise growth and survival of astrocytoma cell lines by regulating reactive oxygen species accumulation. Cancer Res 67, 3741-3751.

9. Bogenrieder T \& Herlyn M (2003) Axis of evil: molecular mechanisms of cancer metastasis. Oncogene 22, 6524-6536.

10. Bourboulia D \& Stetler-Stevenson WG (2010) Matrix metalloproteinases (MMPs) and tissue inhibitors of metalloproteinases (TIMPs): positive and negative regulators in tumor cell adhesion. Semin Cancer Biol 20, 161-168.
11. Mekkawy AH, Morris DL \& Pourgholami MH (2009) Urokinase plasminogen activator system as a potential target for cancer therapy. Future Oncol 5, 1487-1499.

12. Yoon SO, Park SJ, Yun CH, et al. (2003) Roles of matrix metalloproteinases in tumor metastasis and angiogenesis. $J$ Biochem Mol Biol 36, 128-137.

13. Kessenbrock K, Plaks V \& Werb Z (2010) Matrix metalloproteinases: regulators of the tumor microenvironment. Cell 141, 52-67.

14. Duffy MJ, McGowan PM \& Gallagher WM (2008) Cancer invasion and metastasis: changing views. J Pathol 214, 283-293.

15. Patriarca C, Macchi RM, Marschner AK, et al. (2011) Epithelial cell adhesion molecule expression (CD326) in cancer: a short review. Cancer Treat Rev 38, 68-75.

16. van der Gun BT, Melchers LJ, Ruiters MH, et al. (2010) EpCAM in carcinogenesis: the good, the bad or the ugly. Carcinogenesis 31, 1913-1921.

17. Folkman J (2002) Role of angiogenesis in tumor growth and metastasis. Semin Oncol 29, 15-18.

18. Fu B, Xue J, Li Z, et al. (2007) Chrysin inhibits expression of hypoxia-inducible factor-1alpha through reducing hypoxiainducible factor-1alpha stability and inhibiting its protein synthesis. Mol Cancer Ther 6, 220-226.

19. Lee DH \& Lee YJ (2008) Quercetin suppresses hypoxiainduced accumulation of hypoxia-inducible factor-1alpha (HIF-1alpha) through inhibiting protein synthesis. J Cell Biochem 105, 546-553.

20. Semenza GL (2006) Development of novel therapeutic strategies that target HIF-1. Expert Opin Ther Targets 10, 267-280.

21. Zhong H, De Marzo AM, Laughner E, et al. (1999) Overexpression of hypoxia-inducible factor 1alpha in common human cancers and their metastases. Cancer Res 59, $5830-5835$.

22. Maxwell PH, Dachs GU, Gleadle JM, et al. (1997) Hypoxiainducible factor-1 modulates gene expression in solid tumors and influences both angiogenesis and tumor growth. Proc Natl Acad Sci U S A 94, 8104-8109.

23. Rankin EB \& Giaccia AJ (2008) The role of hypoxia-inducible factors in tumorigenesis. Cell Death Differ 15, 678-685.

24. Hicklin DJ \& Ellis LM (2005) Role of the vascular endothelial growth factor pathway in tumor growth and angiogenesis. $J$ Clin Oncol 23, 1011-1027.

25. Semenza GL (2007) Evaluation of HIF-1 inhibitors as anticancer agents. Drug Discov Today 12, 853-859.

26. Kwon GT, Cho HJ, Chung WY, et al. (2009) Isoliquiritigenin inhibits migration and invasion of prostate cancer cells: possible mediation by decreased JNK/AP-1 signaling. J Nutr Biochem 20, 663-676.

27. Kim EJ, Kang Y-H, Schaffer BS, et al. (2002) Inhibition of Caco-2 cell proliferation by all-trans retinoic acid (tRA): role of insulin-like growth factor binding protein-6. J Cell Physiol 190, 92-100.

28. Cho HJ, Kim WK, Kim EJ, et al. (2003) Conjugated linoleic acid inhibits cell proliferation and ErbB3 signaling in HT29 human colon cell line. Am J Physiol Gastrointest Liver Physiol 284, G996-1005.

29. Park SY, Lim SS, Kim JK, et al. (2010) Hexane-ethanol extract of Glycyrrbiza uralensis containing licoricidin inhibits the metastatic capacity of DU145 human prostate cancer cells. Br J Nutr 104, 1272-1282.

30. Kwon GT, Jung JI, Song HR, et al. (2011) Piceatannol inhibits migration and invasion of prostate cancer cells: possible mediation by decreased interleukin-6 signaling. J Nutr Biochem 23, 228-238. 
31. Zhao W, Wang YS, Hui YN, et al. (2008) Inhibition of proliferation, migration and tube formation of choroidal microvascular endothelial cells by targeting HIF-1alpha with short hairpin RNA-expressing plasmid DNA in human RPE cells in a coculture system. Graefes Arch Clin Exp Ophthalmol 246, $1413-1422$

32. Maxwell PH, Wiesener MS, Chang GW, et al. (1999) The tumour suppressor protein VHL targets hypoxia-inducible factors for oxygen-dependent proteolysis. Nature 399 , $271-275$

33. Chaffer CL \& Weinberg RA (2011) A perspective on cancer cell metastasis. Science 331, 1559-1564.

34. Woessner JF Jr (1991) Matrix metalloproteinases and their inhibitors in connective tissue remodeling. FASEB $J \mathbf{5}$ 2145-2154.

35. Christofori G (2006) New signals from the invasive front Nature 441, 444-450.

36. Yao H, Wang H, Zhang Z, et al. (2008) Sulforaphane inhibited expression of hypoxia-inducible factor-1alpha in human tongue squamous cancer cells and prostate cancer cells. Int J Cancer 123, 1255-1261.

37. Li C, Yang Z, Zhai C, et al. (2010) Maslinic acid potentiates the anti-tumor activity of tumor necrosis factor alpha by inhibiting NF-kappaB signaling pathway. Mol Cancer 9, 73.

38. Semenza GL (2002) HIF-1 and tumor progression: pathophysiology and therapeutics. Trends Mol Med 8, S62-S67.

39. Zhong H, Chiles K, Feldser D, et al. (2000) Modulation of hypoxia-inducible factor 1alpha expression by the epidermal growth factor/phosphatidylinositol 3-kinase/PTEN/AKT/ FRAP pathway in human prostate cancer cells: implications for tumor angiogenesis and therapeutics. Cancer Res 60, $1541-1545$.
40. Dimova EY, Michiels C \& Kietzmann T (2009) Kinases as upstream regulators of the HIF system: their emerging potential as anti-cancer drug targets. Curr Pharm Des 15, $3867-3877$.

41. Blancher C, Moore JW, Robertson N, et al. (2001) Effects of ras and von Hippel-Lindau (VHL) gene mutations on hypoxia-inducible factor (HIF)-1alpha, HIF-2alpha, and vascular endothelial growth factor expression and their regulation by the phosphatidylinositol $3^{\prime}$-kinase/Akt signaling pathway. Cancer Res 61, 7349-7355.

42. Jiang BH, Jiang G, Zheng JZ, et al. (2001) Phosphatidylinositol 3-kinase signaling controls levels of hypoxia-inducible factor 1. Cell Growth Differ 12, 363-369.

43. Liu LZ, Li C, Chen Q, et al. (2011) MiR-21 induced angiogenesis through AKT and ERK activation and HIF-1alpha expression. PLoS One 6, e19139.

44. Allouche Y, Jimenez A, Uceda M, et al. (2009) Triterpenic content and chemometric analysis of virgin olive oils from forty olive cultivars. J Agric Food Chem 57, 3604-3610.

45. Perez-Camino MC \& Cert A (1999) Quantitative determination of hydroxy pentacyclic triterpene acids in vegetable oils. J Agric Food Chem 47, 1558-1562.

46. Fernandez-Navarro M, Peragon J, Esteban FJ, et al. (2010) Maslinic acid: a component of olive oil on growth and protein-turnover rates. In Olives and Olive Oil in Health and Disease Prevention, pp. 1415-1421 [V Preedy and RR Watson, editors]. Oxford: Academic Press.

47. Vissers MN, Zock PL \& Katan MB (2004) Bioavailability and antioxidant effects of olive oil phenols in humans: a review. Eur J Clin Nutr 58, 955-965. 